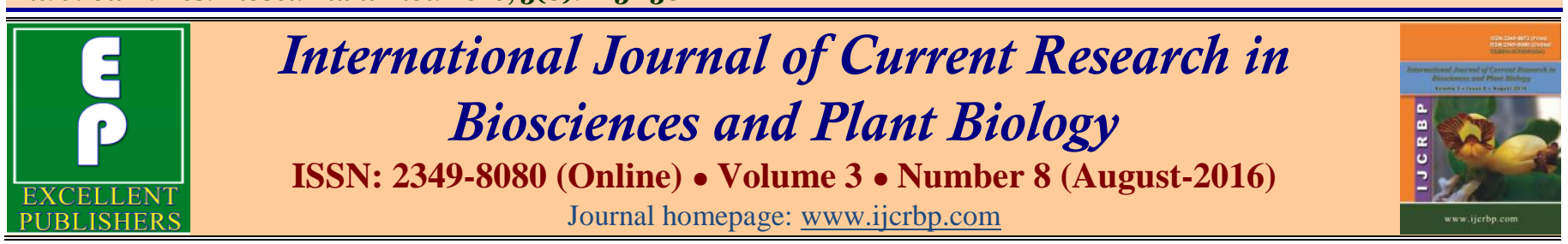

\title{
Physiological Parameters, Leaf Nitrogen Content and Grain Yield of Finger Millet as Affected by Different Sources of Organic Manures under INM in Comparison with RDF
}

\author{
Ch. Pallavi ${ }^{1 *}$, B. Joseph ${ }^{2}$, M.A. Aariff Khan ${ }^{3}$ and S. Hemalatha 4 \\ ${ }^{1}$ Ph.D. Scholar, Department of Agronomy, College of Agriculture, Professor Jayashankar Telangana State Agricultural \\ University, Rajendranagar, Hyderabad -500030, Telangana State, India \\ ${ }^{2}$ Principal Scientist (Agronomy) and Head, RS \& RRS, Rudrur, Address: University officers quarter No.1, PJTSAU campus, \\ Rajendranagar, Hyderabad, 500030, Telangana State, India \\ 3Principal Scientist (Soil Science), AICRP on Agroforestry, PJTSAU campus, Rajendranagar, Hyderabad - 5oo o3o, \\ Telangana State, India \\ 4Principal Scientist (Agronomy), Farmers Call Centre, Acharya N.G. Ranga Agricultural University (ANGRAU), Rajendranagar, \\ Hyderabad - 500 o3o, Telangana State, India \\ *Corresponding author.
}

\begin{abstract}
A b stract
Finger millet was grown under three year old Melia azedarach in red sandy loam soil with different management options viz., application of farm yard manure (FYM) @ $10 \mathrm{t} \mathrm{ha}^{-1}, 100 \%$ recommended dose of fertilizer (RDF) (40:20:20 NPK kg ha $\left.{ }^{-1}\right)$ alone, and in conjunction with $75 \% \mathrm{RD} \mathrm{N}$ with $25 \% \mathrm{~N}$ through FYM, Vermicompost, Poultry manure; also with biofertilizers@ $5 \mathrm{~kg} \mathrm{ha}^{-1}$ Azospirillum and phosphate solubilizing bacteria (PSB) along with finger millet alone as sole cropping with $100 \%$ RDF. The physiological parameters such as LAI, CGR, NAR and SPAD values (leaf nitrogen content) were recorded at critical growth stages of the crop along with grain yield of finger millet. The physiological parameters such as LAI, CGR, NAR and SPAD values (leaf nitrogen content) were recorded at critical growth stages of the crop along with grain yield of finger millet. Higher physiological parameters and grain yield of rice was recorded with the INM practice followed by recommended dose of fertilizers (RDF) treatment. Among the organic treatments, higher grain yield of finger millet was recorded with sole crop on par with $75 \% \mathrm{RD} \mathrm{N}+25 \% \mathrm{~N}$ poultry manure $\left(2405 \mathrm{~kg} \mathrm{ha}^{-1}\right)$ and $100 \% \mathrm{RDF}(2393 \mathrm{~kg}$ $\left.\mathrm{ha}^{-1}\right)$. The lowest grain $\left(1583 \mathrm{~kg} \mathrm{ha}^{-1}\right)$ was found with control FYM @ $10 \mathrm{t} \mathrm{ha}^{-1}$ i.e., farmers practice. Similar trend was observed for all the physiological parameters recorded and harvest index of the rice crop. From the present investigation, it can be inferred that, among nutrient management practices tested, 75\% RD N $+25 \% \mathrm{~N}$ poultry manure and $100 \%$ RDF in agri-silviculture system was better for realizing higher grain yield and physiological parameters apart from sustaining better soil nutrient status on sandy loam soils of Southern Telangana region of Andhra Pradesh.
\end{abstract}

\footnotetext{
Abbreviations: AM-Arbuscular mycorrhiza; CGR-Crop growth rate; DAS-Days after sowing; INM-Integrated nutrient management; FYM-Farm yard manure; LAI-Leaf area index; NAR-Net assimilation rate; PSB-Phosphate solubilizing bacteria; RDF-Recommended dose of fertilizer; RD N-Recommended dose of nitrogen.
}

\section{Article Info}

Accepted: 31 July 2016

Available Online: 06 August 2016

Ke yword s

Crop growth rate

Eleusine coracana

Grain yield

Organic manure

Vermicompost 


\section{Introduction}

Finger millet is valued by traditional farmers as a low fertilizer input crop, under these conditions, it suffers from low yields (Rurinda et al., 2014). Most of the soils in the semi-arid tropics, where finger millet is grown, are deficient in major and micronutrients, mainly due to continuous cropping, low use of mineral fertilizer, poor recycling of crop residues, and low rates of organic matter application which can limit yield potential (Rao et al., 2012). Therefore, it is important to optimize nutrient management practices and other related factors affecting finger millet cultivation in order to attain better yields under the comparatively marginal local growing conditions. Unfortunately, compared to the major cereal crops, the recommendations available for nutrient management in finger millet are scarce, limiting the ability of agricultural extension officers to assist subsistence farmers.

Nitrogen is the most limiting nutrient in finger millet (Eleusine coracana L.) production and growers continue to be faced with the challenge of meeting crop $\mathrm{N}$ demand particularly in organic production system. The world's arable land resources are finite and there is not much scope for significantly expanding the area of land under cultivation. Hence, most of the increase in agricultural production will have to be obtained through increased productivity from the existing agricultural land. This can be achieved by improved management practices in general and fertilizer management in practices in particular. The problem is compounded by the fact that majority of the farmers in rainfed area are resources poor with low risk bearing capacity and they generally do not apply recommended dose of fertilizer either organic and inorganic sources.

The vermicompost has been advocated as good organic manure for use in integrated management practices in the millet crops particularly on finger millet. Use of vermicompost as a biofertilizer and substitute for chemical fertilizer is advised by pioneers of organic farming (Rajkhowa et al., 2000). Vermicompost would not only increase organic carbon status of the soils but also increase the soil water holding capacity. Flocculation of soil and availability of all micro and macro nutrients, thus making the soil and crop production sustainable one (Daisy et al., 2013). Addition of FYM and other organic manures improves the soil physical properties such as soil structure, reduces compaction and crusting of soil thereby increasing nitrogen fixation by microorganisms (Gandhi and
Sivakumar, 2010). With respect to biofertilizers, finger millet plants treated with different strains of arbuscular mycorrhizal (AM) fungi showed significantly different effects on plant growth and yield. Furthermore, variability for plant growth responses to inoculation with AM fungi by different finger millet crop. Combined, these results highlight the importance of considering the finger millet cultivar effect as well as the strain effect of AM fungi. Keeping these facts in view, the different sources of organic manures in comparison with RDF and INM practices to complete the organic nutrition of finger millet on physiological parameters, leaf nitrogen content and grain yield finger millet under agri-silviculture system on sandy loam soils of Southern Telangana region of Andhra Pradesh.

\section{Materials and methods}

Field experiment was conducted with finger millet at agroforestry research block, Acharya N.G Ranga Agricultural University campus, Rajendranagar, Hyderabad during kharif, 2013. The weekly mean maximum temperature during the crop growth period ranged from 27.8 to $33.5^{\circ} \mathrm{C}$ with an average of $30.5^{\circ} \mathrm{C}$, while the weekly mean minimum temperature ranged from $17.7^{\circ} \mathrm{C}$ to $25.0^{\circ} \mathrm{C}$ with an average of $21.6^{\circ} \mathrm{C}$. The total rainfall received during the crop growth period was $437.1 \mathrm{~mm}$ distributed in 30 rainy days. The experimental soil was Alfisol with sandy loam texture with $\mathrm{pH}$ (7.57), EC $\left(0.195 \mathrm{dSm}^{-1}\right)$ and OC $(0.75 \%)$. The soil was medium in available nitrogen $\left(259.2 \mathrm{~kg} \mathrm{ha}^{-1}\right)$, phosphorus $\left(40.85 \mathrm{~kg} \mathrm{ha}^{-1}\right)$ and high in available potassium (352.1 $\left.\mathrm{kg} \mathrm{ha}^{-1}\right)$.

The field experiment consisted of nine treatments which were laid out in Randomized Block Design, replicated thrice and square planting $(15 \times 15 \mathrm{~cm})$. Among nine treatments, three integrated nutrient management practice treatments with $75 \% \mathrm{RD} \mathrm{N}$ with inorganic manure and $25 \%$ combination of each organic manure (farmyard manure, vermicompost and poultry manure). These treatments were compared with the recommended dose of fertilizer (RDF) among sole cropping and under agri-silviculture system. The finger millet variety PRS-2 with field duration of 95 days was used in the trial. All other package of practices were carried out as per recommendation for INM and RDF treatments. Irrigation and plant protection measures were followed uniformly in all the plots as per the requirements during experimentation. On $\mathrm{N}$ equivalent basis, required quantities of farmyard manure, decomposed poultry manure and vermicompost were applied in the soil 
before one week of sowing the crop. Different sources of organic manures were applied as per treatment schedule. Recommended doses of 40:20:20 kg ha ${ }^{-1}$ of N, P and K in the form of urea, single super phosphate and muriate of potash were applied to the finger millet crop in respect of treatment $\mathrm{T}_{2}$ and $\mathrm{T}_{9}$ (RDF Treatment). In addition to this, application of $5 \mathrm{~kg} \mathrm{ha}^{-1}$ of Azospirillum and $5 \mathrm{~kg}$ $\mathrm{ha}^{-1}$ of phosphobacteria were applied as seed treatment alone and in combination as three treatments along with $75 \%$ RD N.

For biometric and yield observations, five plants in each plot were selected at random and tagged. These plants were used for recording biometric observation at different stages of crop growth. The harvested produce from each net plot was threshed, sun dried, winnowed separately and the finger millet grain yield was recorded at $14 \%$ moisture content and expressed in $\mathrm{kg} \mathrm{ha}^{-1}$ (Watson, 1947).

\section{Physiological parameters}

Various physiological parameters were computed from the data obtained on dry weight of different plant parts and leaf area.

\section{Leaf area index (LAI)}

Leaf area was estimated on two plants in each plot at 30, 45, 60, 75 DAS and at harvest stages. The area of total leaves was measured with digital leaf area meter (LI3100) and expressed in $\mathrm{cm}$. Leaf area index was calculated by using the formula as proposed by Watson (1952).

$$
\mathrm{LAI}=\frac{\text { Leaf area }}{\text { Unit ground area }}
$$

\section{Crop growth rate (CGR)}

The CGR indicates an increase in dry matter per unit land area per unit time. It was calculated by using the formula suggested by Peng et al. (1993). It was estimated between 30, 45, 60, 75 DAS and at harvest stages and expressed in $\mathrm{g} \mathrm{m}^{-2}$ day $^{-1}$.

$$
\mathrm{CGR}=\frac{\mathrm{W}_{2}-\mathrm{W}_{1}}{\mathrm{t}_{2}-\mathrm{t}_{1}} \times \frac{1}{\mathrm{P}}
$$

Where, $\mathrm{W}_{1}$ and $\mathrm{W}_{2}$ - Whole plant dry weight at time $\mathrm{t}_{1}$ and $t_{2}$ respectively, $P$ - Ground area occupied by the plant $\left(\mathrm{m}^{2}\right)$, and $\mathrm{t}_{1}$ and $\mathrm{t}_{2}$ - Time interval in days.

\section{Relative Growth Rate (RGR)}

RGR is the rate of increase in dry weight per unit time and was calculated by using the formula suggested by Radford (1967). It was estimated between 30, 45, 60, 75 DAS and at harvest stages and expressed in $\mathrm{g} \mathrm{g}^{-1}$ day $^{-1}$.

$$
\mathrm{RGR}=\frac{\log _{\mathrm{e}} \mathrm{W}_{2}-\mathrm{Log}_{\mathrm{e}} \mathrm{W}_{1}}{\mathrm{t}_{2}-\mathrm{t}_{1}}
$$

Where, $\mathrm{W}_{1}$ and $\mathrm{W}_{2}$ - Whole plant dry weight at time $\mathrm{t}_{1}$ and $t_{2}$ respectively, and $t_{1}$ and $t_{2}$ - Time interval in days.

\section{Net assimilation rate (NAR)}

The NAR is the measure of photosynthetic product that is partitioned to form the plant materials. The NAR during the crop growth period was estimated between 30 , $45,60,75 \mathrm{DAS}$ and at harvest stages by using the following formula suggested by Yoshida (1981) and expressed in $\mathrm{mg} \mathrm{cm}^{-2}$ day $^{-1}$.

$$
\mathrm{NAR}=\frac{\mathrm{W}_{2}-\mathrm{W}_{1}}{\mathrm{t}_{2}-\mathrm{t}_{1}} \times \frac{\log _{\mathrm{e}} \mathrm{L}_{2}-\log _{\mathrm{e}} \mathrm{L}_{1}}{\mathrm{~L}_{2}-\mathrm{L}_{1}}
$$

Where, $L_{1}$ and $L_{2}$ - Leaf area at time $t_{1}$ and $t_{2}$, respectively; $\mathrm{W}_{1}$ and $\mathrm{W}_{2}$ - Whole plant dry weight at time $t_{1}$ and $t_{2}$, respectively; $t_{1}$ and $t_{2}$ - Time intervals in days.

\section{Leaf nitrogen content / SPAD values (chlorophyll} meter value)

The chlorophyll meter (Minolta, SPAD 502 meter) was used for nondestructive data collection on chlorophyll and nitrogen status which measures relative greenness of the leaves in a rapid manner. SPAD values of intact leaves as described by Pillai and Vamadevan (1978). Observations were recorded at 30, 45, 60, 75 DAS and at harvest stages flowering stage by taking five observations per leaf around the midpoint of each leaf blade, $30 \mathrm{~cm}$ apart on upper (dorsal) side of midrib. Readings from five plants i.e., 25 readings, were averaged to represent the mean SPAD values of each plot.

\section{Statistical analysis}

The data on various characters studied during the course of investigation were statistically analysed by applying the technique of analysis of variance for randomized block design as suggested by Panse and Sukhatme 
(1978). Wherever treatment differences were significant ("F" test), critical differences were worked out at five per cent probability level. Treatment differences that were not significant were denoted as "NS".

\section{Results and discussion}

\section{Leaf area index (LAI)}

The mean LAI at different growth period at $30,45,60,75$ DAS and harvest are 0.66, 1.67, 2.52, 3.49 and 2.82 (Table 2). As the crop growth period increased from 30 to 75 DAS the LAI was also increased gradually from 0.66 to 3.49 and later decreased at harvest (2.82). The LAI was significantly influenced by different treatments over control. The highest LAI at 75 DAS was recorded in sole crop (4.06) followed by integrated nutrient management practices i.e. $75 \% \mathrm{RD} \mathrm{N}+25 \% \mathrm{~N}$ poultry manure (3.83) and $75 \% \mathrm{RD} \mathrm{N}+25 \% \mathrm{~N}$ vermicompost (3.82) (Fig. 1).

A significant increase in LAI of sole crop $(0.82,2.02$, $3.01,4.06$ and 3.43) at 30, 45, 60, 75 DAS and harvest was observed over control $(0.58,1.22,1.95,2.50$ and 1.82). Among different nitrogen sources at $30,45,60,75$ DAS and harvest in agri-silviculture system, the highest LAI with $75 \% \mathrm{RD} \mathrm{N}+25 \% \mathrm{~N}$ poultry manure and $100 \%$ RDF followed by $75 \% \mathrm{RD} \mathrm{N}+25 \% \mathrm{~N}$ vermicompost and $75 \% \mathrm{RD} \mathrm{N}+$ Azospirillum + PSB. At maturity, irrespective of the treatments the LAI decreased compared to 75 DAS. However, sole crop had shown higher LAI (3.43) at harvest followed by $75 \% \mathrm{RD} \mathrm{N}+$ $25 \% \mathrm{~N}$ vermicompost (3.12), $75 \% \mathrm{RD} \mathrm{N}+25 \% \mathrm{~N}$ poultry manure (3.09), 75\% RD N + Azospirillum + PSB (2.91) and $100 \%$ RDF (2.90). The LAI increased up to 60 DAS and afterwards, it declined. High LAI at 60 DAS might be due to more light interception and enhanced photosynthetic rate (NAR), which ultimately resulted in higher dry matter production, straw yield, test weight, grain weight earhead ${ }^{-1}$ and grain yield. These are in conformity with the findings of Patil et al. (2005) in sweet sorghum. Muniyappa and Naik (1995) also observed relationship with leaf area and distribution of sugars and starch into stem and grain in sweet sorghum cultivars as LAI play crucial role in enhancing the photosynthetic assimilation.

\section{Crop growth rate (CGR)}

The CGR was significantly influenced in finger millet as the crop advances during flowering to harvest phase (Table 1). CGR of finger millet at 60-75 DAS and 75 DAS to maturity varied from 6.669-4.429 and 5.422-
$1.982 \mathrm{~g} \mathrm{~m}^{-2} \mathrm{~d}^{-1}$ with a mean 2.779 and $3.775 \mathrm{~g} \mathrm{~m}^{-2} \mathrm{~d}^{-1}$ respectively. The INM practice $\left(\mathrm{T}_{4}\right)$ recorded higher crop growth rate $\left(6.669 \mathrm{~g} \mathrm{~m}^{-2}\right.$ day $\left.^{-1}\right)$ at flowering and $\mathrm{T}_{5}$ has recorded maximum CGR $\left(5.035 \mathrm{~g} \mathrm{~m}^{-2}\right.$ day $\left.^{-1}\right)$ at harvest phase. However, it was comparable with recommended NPK fertilizers $\left(\mathrm{T}_{9}\right.$ and $\mathrm{T}_{2}$ ) at harvest (5.422 and 4.918). Rapid increase in CGR after earhead formations resulted in increased accumulation of dry matter in the reproductive organs and economic sinks. As such higher CGR at all growth stages resulted in higher total dry matter, better partitioning of dry matter, more grain and straw yield in finger millet. These findings are in conformity with those of Veerabadhran and Kennedy (2001) in sorghum.

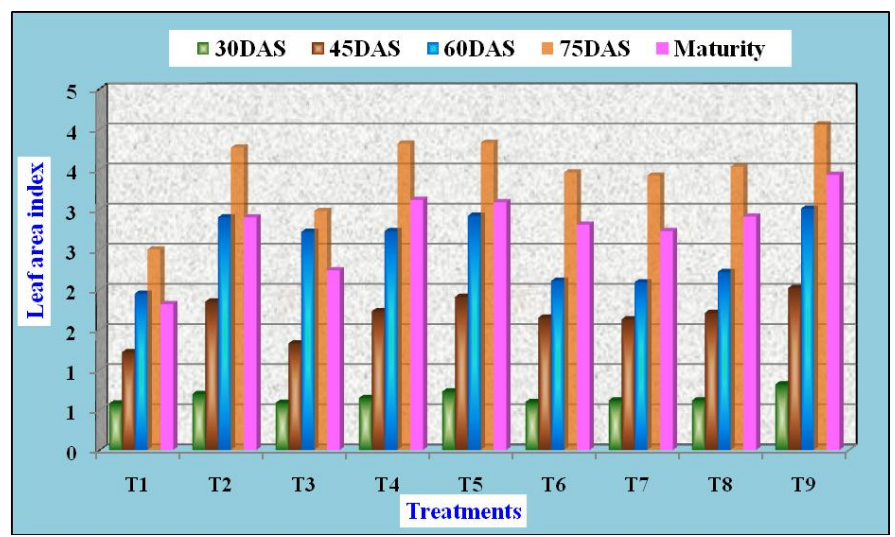

Fig. 1: Leaf area index of finger millet as influenced by nutrient management in Melia azedarach based agrisilviculture system (Treatments: $\mathrm{T}_{1}$-FYM @ $10 \mathrm{t} \mathrm{ha}{ }^{-1} ; \mathrm{T}_{2}-100 \%$ RDF; $\mathrm{T}_{3}-75 \% \mathrm{~N}+25 \% \mathrm{~N} \mathrm{FYM} ; \mathrm{T}_{4}-75 \% \mathrm{RD} \mathrm{N}+25 \% \mathrm{~N}$ Vermicompost; $\mathrm{T}_{5}-75 \%$ RD N $+25 \% \mathrm{~N}$ Poultry manure; $\mathrm{T}_{6}-75 \% \mathrm{RD}$ $\mathrm{N}+$ Azospirillum; $\mathrm{T}_{7}-75 \% \mathrm{RD} \mathrm{N}+\mathrm{PSB} ; \mathrm{T}_{8}-75 \% \mathrm{RD} \mathrm{N}+$ Azospirillum + PSB; T9-Sole crop without trees).

\section{Relative growth rate (RGR)}

RGR was significantly influenced in finger millet as the crop advances during flowering to harvest phase (Table $1)$. RGR of finger millet ranged from $0.0528-0.0315$, $0.0485-0.0340,0.0350-0.0154$ and $0.0382-0.0129 \mathrm{~g} \mathrm{~g}^{-1} \mathrm{~d}^{-}$ ${ }_{1}^{1}$ with a mean $0.0425,0.0378,0.0199$ and $0.0293 \mathrm{~g} \mathrm{~g}^{-1} \mathrm{~d}^{-}$ ${ }^{1}$ respectively at 30-45, 45-60, 60-75 DAS and 75 DAS to maturity. Maximum RGR in finger millet was obtained at 30-45 DAS which gave a push to the transition to flowering with reduction from 60-75 DAS and there after reduced at maturity. Similar decrease in RGR with crop age in prosomillet having higher RGR recorded more grain yield (Dhawale et al., 2003). Veerabadhran and Kennedy (2001) also reported higher values of NAR, RGR and CGR with increasing yield in sorghum. These observations confirmed findings of the present investigation. 


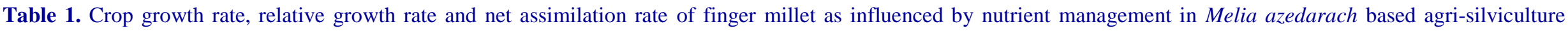
system.

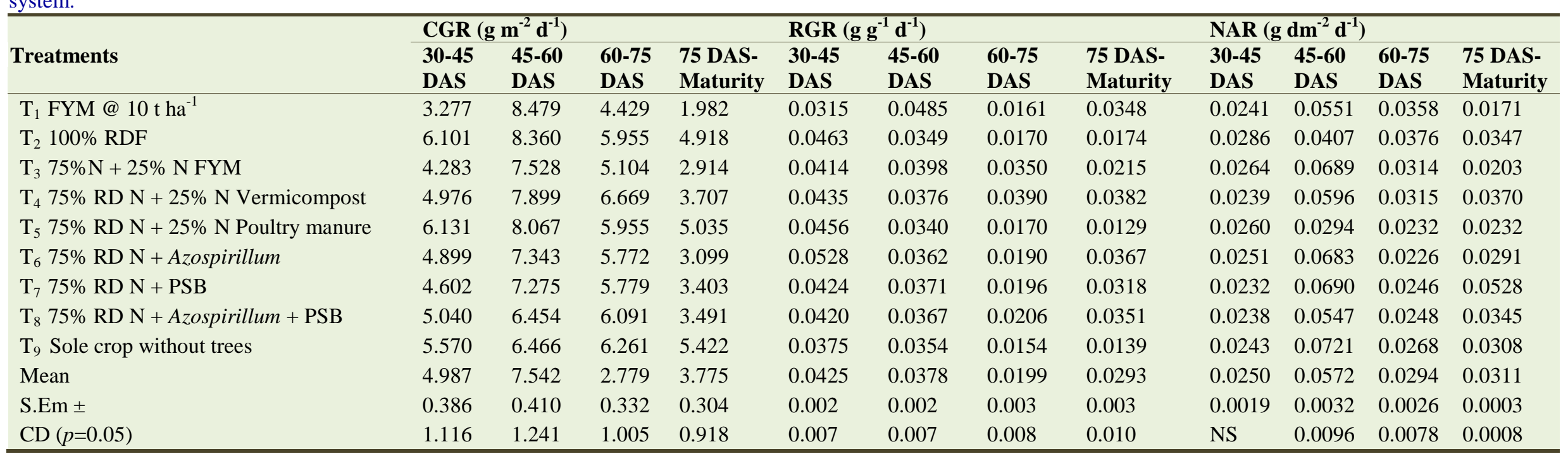

Table 2. Yield, Leaf area index and SPAD values of finger millet as influenced by nutrient management in Melia azedarach based agri-silviculture system.

\begin{tabular}{|c|c|c|c|c|c|c|c|c|c|c|c|}
\hline \multirow{2}{*}{ Treatments } & \multirow{2}{*}{$\begin{array}{l}\text { Grain } \\
\text { yield } \\
\left(\mathrm{kg} \mathrm{ha}^{-1}\right)\end{array}$} & \multicolumn{5}{|l|}{ LAI } & \multicolumn{5}{|c|}{ SPAD values } \\
\hline & & 30 DAS & 45 DAS & 60 DAS & 75 DAS & Maturity & 30 DAS & 45 DAS & 60 DAS & 75 DAS & Maturity \\
\hline $\mathrm{T}_{1}$ FYM @10 tha & 1583 & 0.58 & 1.22 & 1.95 & 2.50 & 1.82 & 26.34 & 27.10 & 24.45 & 25.99 & 24.83 \\
\hline $\mathrm{T}_{2} 100 \% \mathrm{RDF}$ & 2393 & 0.70 & 1.85 & 2.90 & 3.77 & 2.90 & 28.23 & 31.38 & 30.30 & 31.24 & 26.93 \\
\hline $\mathrm{T}_{3} 75 \% \mathrm{~N}+25 \% \mathrm{~N} F Y M$ & 1828 & 0.59 & 1.33 & 2.72 & 2.98 & 2.57 & 26.99 & 28.03 & 28.05 & 27.70 & 26.67 \\
\hline $\mathrm{T}_{4} 75 \% \mathrm{RD} \mathrm{N}+25 \% \mathrm{~N}$ Vermicompost & 2216 & 0.65 & 1.73 & 2.73 & 3.82 & 3.12 & 27.65 & 30.89 & 30.13 & 30.94 & 26.83 \\
\hline $\mathrm{T}_{5} 75 \% \mathrm{RD} \mathrm{N}+25 \% \mathrm{~N}$ Poultry manure & 2405 & 0.73 & 1.91 & 2.92 & 3.83 & 3.09 & 28.23 & 31.78 & 30.37 & 31.35 & 27.31 \\
\hline $\mathrm{T}_{6} 75 \% \mathrm{RD} \mathrm{N}+$ Azospirillum & 1977 & 0.60 & 1.65 & 2.11 & 3.46 & 2.81 & 27.39 & 29.79 & 29.83 & 29.72 & 26.45 \\
\hline $\mathrm{T}_{7} 75 \% \mathrm{RD} \mathrm{N}+\mathrm{PSB}$ & 1954 & 0.62 & 1.63 & 2.09 & 3.42 & 2.73 & 27.13 & 28.92 & 28.98 & 28.72 & 26.39 \\
\hline $\mathrm{T}_{8} 75 \% \mathrm{RD} \mathrm{N}+$ Azospirillum $+\mathrm{PSB}$ & 2126 & 0.62 & 1.71 & 2.22 & 3.53 & 2.91 & 27.18 & 30.03 & 29.91 & 30.25 & 26.61 \\
\hline $\mathrm{T}_{9}$ Sole crop without trees & 2681 & 0.82 & 2.02 & 3.01 & 4.06 & 3.43 & 33.87 & 34.12 & 32.13 & 35.71 & 29.03 \\
\hline Mean & 2129 & 0.66 & 1.67 & 2.52 & 3.49 & 2.82 & 28.18 & 30.18 & 29.35 & 30.18 & 26.74 \\
\hline S.Em \pm & 102 & 0.006 & 0.09 & 0.02 & 0.04 & 0.12 & 0.79 & 1.30 & 0.76 & $0 . .94$ & 0.61 \\
\hline $\mathrm{CD}(p=0.05)$ & 310 & 0.018 & 0.05 & 0.07 & 0.12 & 0.36 & 2.40 & 3.93 & 2.29 & 2.85 & 1.85 \\
\hline
\end{tabular}




\section{Net assimilation rate (NAR)}

The NAR was significantly influenced in finger millet as the crop advances during flowering to harvest phase (Table 1). NAR of finger millet varied between 0.0286$0.0232,0.0721-0.0294,0.0376-0.0226$ and 0.0528 $0.0171 \mathrm{~g} \mathrm{dm}^{-2} \mathrm{~d}^{-1}$ with a mean $0.0250,0.0572,0.0294$ and $0.0311 \mathrm{~g} \mathrm{dm}^{-2} \mathrm{~d}^{-1}$ respectively at 30-45, 45-60, 60-75 DAS and 75 DAS to maturity.

Maximum NAR in general was obtained at 45-60 DAS and there after reduced gradually to reach a minimum level at maturity, which may be due to severe mutual shading and senescence of older leaves as with an increase the age or growth advances. The increased demand for assimilates is due to rapid growth of stem and grain filling. Uniform distribution of solar radiation throughout the crop canopy and efficient absorption of nutrients ensure more NAR and RGR, which may lead to higher productivity of crop. Thus physiological parameters like NAR, RGR vary in the cultivars according to growth stages and environmental conditions prevailing during growth period (Nayeem, 1980). Veerabadhran and Kennedy (2001) also observed higher value of NAR, RGR and CGR with increasing yield in sorghum.

\section{Finger millet leaf $\mathbf{N}$ content (SPAD value)}

The treatments imposed had significant influence on leaf nitrogen content (SPAD values) during crop growth period (Table 2). SPAD values of finger millet at 30, 45, 60, 75 DAS and maturity ranged from 26.34-33.87, 27.10-34.12, 24.45-32.13, 25.99-35.71 and 24.83-29.03 with a mean 28.18, 30.18, 29.35, 30.18 and 26.74 respectively. SPAD meter values indicates relative green colour existing in the crop canopy. SPAD values recorded at 15 days interval from 30 DAS to harvest. SPAD values were found to increase with time from 30 to 60 DAS and declined gradually to harvest in all treatments. The maximum SPAD readings at 75 DAS observed in $\mathrm{T}_{9}$ (35.71) followed by $\mathrm{T}_{5}(31.35), \mathrm{T}_{2}$ (31.24), $\mathrm{T}_{4}$ (30.94), $\mathrm{T}_{8}$ (30.25), $\mathrm{T}_{6}$ (29.72), $\mathrm{T}_{7}$ (28.72), $\mathrm{T}_{3}(27.70)$ and minimum in $\mathrm{T}_{1}(25.99)$ respectively.

The SPAD meter values indicated chlorophyll content indirectly in leaves in the crop canopy. The value increased gradually and reached a peak at 75 DAS and then started declining. It indicates that greenness in crop canopy that start decreasing after 75 DAS. Gradual loss of plant growth promoter activity over a period of time as they are photolabile and relatively unstable in vivo as well as in vitro system. The gradual decrease in SPAD value can be attributed to decrease in applied soil nitrogen due to leaching or by volatization loss (Sekharkumar, 2004).

\section{Grain yield}

Grain yield significantly affected by the judicious use of inorganic fertilizer with organic manures, Poultry manure, Vermicompost, FYM and biofertilizers i.e., Azospirillum and PSB (Table 2). The highest grain yield $\left(2681 \mathrm{~kg} \mathrm{ha}^{-1}\right)$ was recorded with sole crop on par with $75 \% \mathrm{RD} \mathrm{N}\left(2405 \mathrm{~kg} \mathrm{ha}^{-1}\right)+25 \% \mathrm{~N}$ through poultry manure (2394 $\mathrm{kg} \mathrm{ha}^{-1}$ ) and $100 \%$ RDF significantly superior over $75 \%$ RD N $+25 \% \mathrm{~N}$ through vermicompost and 75\% RD N + Azospirillum + PSB. The percentage increase in grain yield with sole crop, $75 \% \mathrm{RD} \mathrm{N}+25 \% \mathrm{~N}$ poultry manure and $100 \% \mathrm{RDF}$ over control was $65.39 \%, 48.37 \%$ and $47.69 \%$ respectively. Among the nutrient management practices followed, biofertilizers combination treatments also performed better than control where only FYM @ $10 \mathrm{t}$ $\mathrm{ha}^{-1}$ was applied. Among them $75 \% \mathrm{RD} \mathrm{N}+$ Azospirillum + PSB (2126 kg ha ${ }^{-1}$ ) was significantly superior to control $\left(1621 \mathrm{~kg} \mathrm{ha}^{-1}\right)$. In terms of percentage, the increase of $34.30,24.89$ and $23.44 \%$ with $75 \%$ RD N + Azospirillum + PSB, 75\% RD N + Azospirillum and 75\% RD N + PSB respectively.

The conjunctive use of organic and inorganic sources has beneficial effect on physiological process of plant metabolism and growth, there by leading to higher grain yield. The easy availability of nitrogen due to mineralization of organics there by influence the shoot and root growth favouring absorption of other nutrients. Similar results were obtained by Yakadri and Reddy (2009), Umesh et al. (2006), Basavaraju and Purushotham (2009). Reduced yield in finger millet compared to sole crop may be ascribed due to competition for light, moisture and nutrients with suppressing effect on crops, reduced solar radiation on crop canopy. Similar results were reported by Deswal and Nandal (2008), Prasad et al. (2011) and Kumar et al. (2013).

\section{Conclusion}

From this study, it was concluded that, higher physiological parameters and grain yield of rice was recorded with the INM practice followed by recommended dose of fertilizers (RDF) treatment. Among the organic treatments, higher grain yield of rice 
was recorded with integrated use of $75 \% \mathrm{RD} \mathrm{N}+25 \% \mathrm{~N}$ through poultry manure and $100 \% \mathrm{RDF}$ is the best nutrient management practice that can be adopted for agri-silviculture system on par with sole crop, which was significantly superior over $75 \% \mathrm{RD} \mathrm{N}+25 \% \mathrm{~N}$ through FYM, 75\% RD N + 25\% N through Vermicompost, 75\% RD N + Azospirillum @ $5 \mathrm{~kg} \mathrm{ha}^{-1}, 75 \% \mathrm{RD} \mathrm{N}+\mathrm{PSB}$, $75 \%$ RD N + Azospirillum + PSB and control in red sandy loam soils to obtain better yields. The different sources of organic manures particularly the composted poultry manure at the rate of $5 \mathrm{t} / \mathrm{ha}$ application had increased the finger millet yield. For organic finger millet production, application of $25 \% \mathrm{RD} \mathrm{N}$ through each organic manures (farmyard manure, vermicompost, poultry manure)for realizing better physiological parameters and grain yield followed by Azospirillum and phosphobacteria combination.

\section{Conflict of interest statement}

Authors declare that they have no conflict of interest.

\section{Acknowledgement}

Financial support from the Department of Agronomy, Acharya N.G. Ranga Agricultural University, Rajendranagar, Hyderabad is gratefully acknowledged.

\section{References}

Basavaraju, T.B., Purushotham, S., 2009. Integrated nutrient management in rainfed ragi (Eleusine coracana $\mathrm{L}$. Gaertn.). Mysore J. Agric. Sci. 43, 366-368.

Daisy, M., Thavaprakash, N., Velayudam, K., Divya, V., 2013. Effect of system of crop intensification (SCI) practices on growth, yield attributes and yield of castor hybrid YRCH1. J. Adv. Life Sci. 6, 366-374.

Deswal, A.K., Nandal, D.P.S., 2008. Growth and yield of wheat (Triticum aestivum) under varying levels of irrigation and fertilizer in eucalyptus based agrisilviculture system. Ind. J. Agrofor. 10, 10-14.

Dhawale, G.N., Hiremath, S.M., Chetti, M.B., 2003. Physiological basis of productivity in prosomillet (Pennisetum miliaceum L.) genotypes. National Seminar of Plant Physiology, December, 2003. pp.12-14.

Gandhi, A., Sivakumar, K., 2010. Impact of vermicompost carrier based bioinoculants on the growth, yield and quality of rice (Oryza sativa L.) CV NLR 145. Ecoscan. 4(1), 83-88.

Kumar, A., Kumar, M., Nandal, D.P.S., Kaushik, N., 2013. Performance of wheat and mustard under Eucalyptus tereticornis based agri-silviculture system. Range Manage. Agrofor. 34, 192-195.
Muniyappa, T.V., Naik, D.C., 1995. Studies on time of harvesting of sweet sorghum genotypes on yield and juice quality for jaggery preparation UAS, Bangalore. J. Maharashtra Agric. Univ. 20(1), 29-30.

Nayeem, K.A., 1980. Genetic studies of quantitative and qualitative characters in grain sorghum (Sorghum bicolor (L.) Moench). Ph.D. Thesis, Marathwada Agricultural University, Pharbani.

Panse, V.G., Sukhatme, P. V., 1978. Statistical Methods for Agricultural Workers. $3^{\text {rd }}$ Edn. Indian Council of Agricultural Research, New Delhi. 361p.

Patil, S.L., Sheelavantar, M. N., Nalatwadmath, S.K., Surkod, V.S.,Mana Mohan, S., Lamani, V.K., 2005. Correlation analysis among soil moisture, soil physico-chemical properties, nutrient uptake and yield of winter sorghum. Ind. J. Agric. Res. 39(3), 177-185

Peng, S., García, F.V., Laza, R.C., Cassman, K.G., 1993. Adjustment for specific leaf weight improves chlorophyll meter's estimate of rice leaf nitrogen concentration. Agron. J. 85(5), 987-990.

Pillai, K.G., Vamadevan, V.K., 1978. Studies on an integrated nutrient supply system for rice. Fert. News. 23, 11.

Prasad, J.V.N.S., Korwar, G.R., Rao, K.V., Srinivas, K., Srinivasarao, C.H., Peddababu, B., Venkateswarulu, B., Rao, S.N., Kulkarni, H.D., 2011. On-farm evaluation of two fast growing trees for biomass production for industrial use in Andhra Pradesh, Southern India. New Forests. 42(1), 51-61.

Radford, P.J., 1967. Growth analysis formulae, their use and abuse. Crop Sci. 7, 171-175.

Rajkhowa, D.J., Gogoi, A.K., Kandali, R., Rajkhowa, K.M., 2000. Effect of vermicompost on greengram nutrition. J. Ind. Soc. Soil Sci. 48(1), 207-208.

Rao, B.K.R., Krishnappa, K., Srinivasarao, C., Wani, S.P., Sahrawat, K.L., Pardhasaradhi, G., 2012. Alleviation of multinutrient deficiency for productivity enhancement of rain-fed soybean and finger millet in the semi-arid region of India. Commun. Soil Sci. Plant Anal. 43, 1427-1435.

Rurinda, J., Mapfumo, P., Van Wijk, M.T., Mtambanengwe, F., Rufino, M.C., Chikowo, R., Giller, K.E., 2014. Comparative assessment of maize, finger millet and sorghum for household food security in the face of increasing climatic risk. Eur. J. Agron. 55, 29-41.

Sekharkumar., 2004. Effect of vermicompost and farmyard manure (FYM) on growth, development and oil composition of medicinal herb krishna tulasi (Ocimum sanctum Linn. /Ocimum tenuiflorum). M.Sc. (Agri.) Thesis. Acharya N.G. Ranga Agricultural University.

Umesh, M.R., Sharanappa, Shrinivasa, K.R., Kumar, K.K.C., 2006. Effect of cropping systems and integrated nutrient management on growth, yield and nutrient uptake of finger millet under rainfed conditions. Crop Res. 31, 366369.

Veerabadhran, K., Kennedy, B., 2001. Correlation and path analysis studies in selected germplasms of sorghum. Madras Agric. J. 88, 309-310. 
Watson, D.J., 1947. Comparative physiological studies on the growth of field crops: I. Variation in net assimilation rate and leaf area between species and varieties, and within and between years. Ann. Bot. 11(41), 41-76.

Watson, D.J., 1952. The physiological basis for variation in yield. Adv. Agron. 6, 103-109.
Yakadri, M., Reddy, A.P.K., 2009. Productivity of pearl millet (Pennisetum glaucum L.) as influenced by planting pattern and nitrogen levels during summer. J. Res. ANGRAU. 37, 34-37.

Yoshida, S., 1981. Fundamentals of rice crop science. IRRI, Los Banos, The Philippines.

\section{How to cite this article:}

Pallavi, Ch., Joseph, B., Aariff Khan, M.A., Hemalatha, S., 2016. Physiological parameters, leaf nitrogen content and grain yield of finger millet as affected by different sources of organic manures under INM in comparison with RDF. Int. J. Curr. Res. Biosci. Plant Biol. 3(8), 123-130.

doi: http://dx.doi.org/10.20546/ijcrbp.2016.308.019 